\title{
Løvinden og lokalcentrene
}

Den senmiddelalderlige sønderjyske bondes omverden

\section{af Bjørn Poulsen}

Landbefolkningens synsfelt og kontaktflader har aldrig været begrænset til blot den hjemlige landsby. Mobiliteten i aldre tider var faktisk stor. Også i senmiddelalderen kom mange bønder i kontakt med verden uden for landsbyskellet. Nogle tog på pilgrimsrejse eller besøgte et nærliggende valfartssted, mange tog til årsmarkeder og endnu flere havde kontakter til en eller flere af byerne. Dr.phil. Bjørn Poulsen belyser her nogle af bøndernes kontakter til omverdenen i 1400-1500’årene.

I årene op mod og lige efter 1500 sprængtes Europas grænser: Portugiserne rundede Afrikas sydspids, Columbus satte foden på Amerikas jord, Magellan sejlede rundt om jorden.

Europas fyrster fulgte levende med i denne udvikling. 1531 besøgte den portugisiske gesandt Damiao de Gois således kong Frederik I på Gottorp slot. Portugiseren, som senere skulle skrive flere bøger, der omhandler opdagelsesrejser, har kunnet bringe sidste nyt om verdens kolonisation til hoffet $\mathrm{i}$ Slesvig. ${ }^{1}$

Også menigmand fik imidlertid lejlighed til at stifte bekendtskab med vidnesbyrd om de fremmede verdener - omend dyreverdener.

Tidligt begyndte omrejsende gøglere og 'menagerier' at fremvise ikkeeuropæiske dyr. 1443 stod en elefant til skue på messen i Frankfurt am Main, og allerede 1450 kunne man se en struds her. Til Nürnberg ankom 1487 en mand med en dromedar, 1491 blev en struds vist frem i byen. 1515 så Albrecht Dürer sammesteds det næsehorn, som han har foreviget i sit berømte stik. ${ }^{2}$

1501 nåede en af disse ufrivillige besøgende fra fremmede verdensdele til Slesvig. I juni måned dette år førte en vognkusk en løvinde fra Hamburg til Gottorp slot. Hertug Frederiks skriver gav kusken 2 rhinske gylden og 6 skilling for kørslen, samt 10 rhinske gylden i drikkepenge. Det var et sjældent syn, som det nok var værd at betale en rund sum for. I en uges tid kunne man så bese løvindens bur, som antagelig stod i slotsgården. Herefter gik det videre. Vognkusken, der hed Jørgen Vorman, modtog af hertugen en håndfuld guldmønter - 20 rhinske gylden - for at køre til næste skueplads: Berlin. I denne by har vel kurfyrsten skullet nyde synet af dyret. ${ }^{3}$

Fyrre år senere, i 1540, hører vi atter om en dyrefremvisning i Slesvig. Ved kroen Langenese, lige uden for Gottorp slot, lokkede da en kamel ung og 


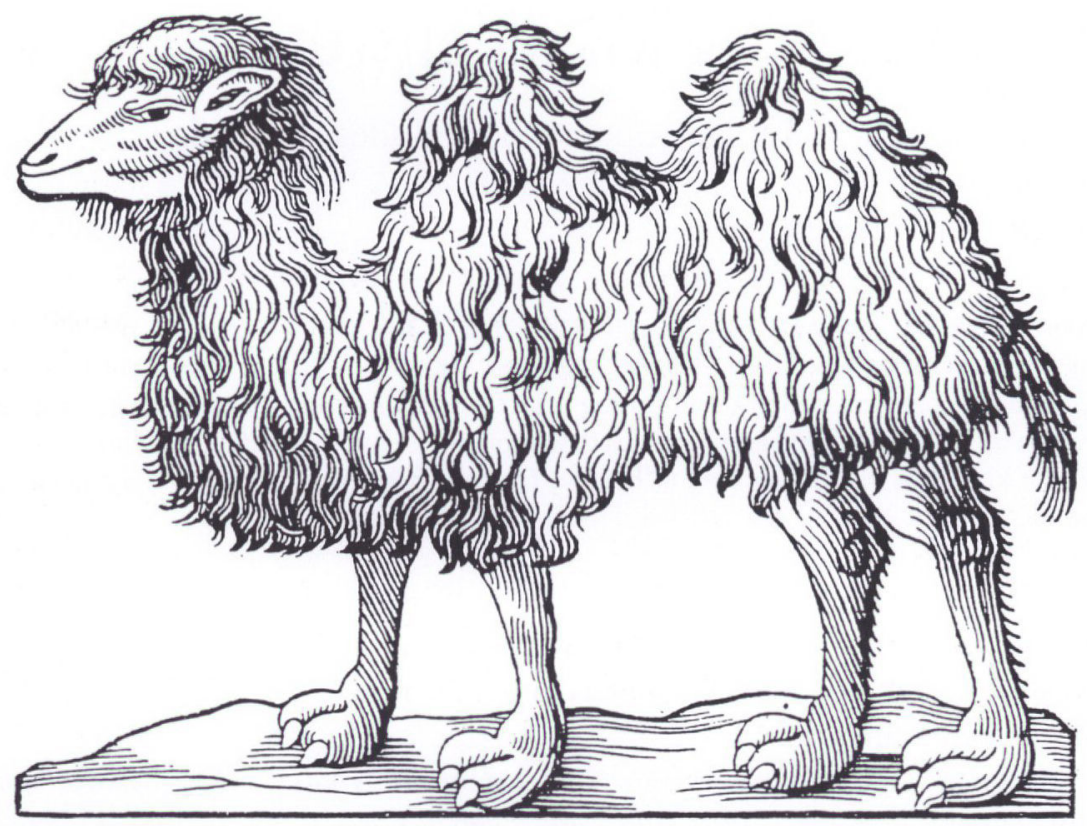

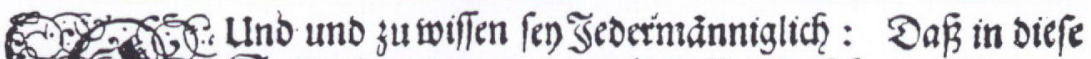
20. Statt ift anfommen eitre fremboe Perjof̨n/ mit stnem (j) wunberlichen Thter/ift genannt Rombartus/fombt aus

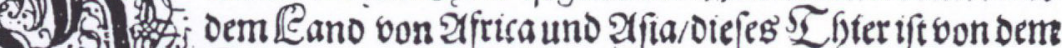

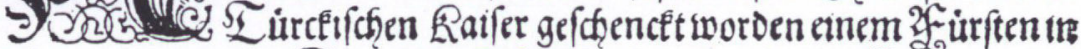

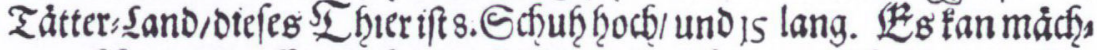

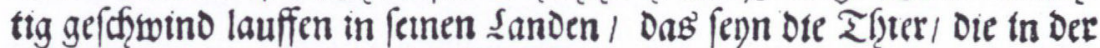
Gand: See ein so.Sretlenlauffen auff etn Saglauch werden fiegebrauche auff oie Poft, fie werden auch gefraucft in Rirtege

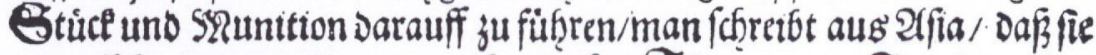

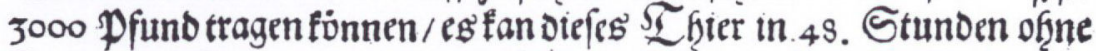
Freffen marchieren / uno wann es frifit/ $p$ frtfites nicht viel auff einmafil es fan aud zu Sommerszeiten 3. SPonatt otine Sauffen leben/wann ess

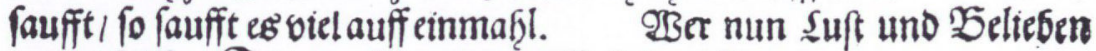

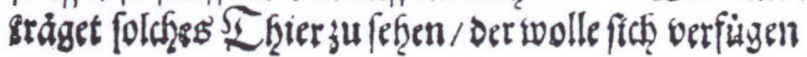

Annoncering af en dromedar-fremvisning $i$ en tysk by. Overalt $i$ Nordeuropa strommede man til, när sjaldne og eksotiske dyr fra fremmede verdensdele var at se.

Trasnit fra omkring 1600, gengivet efter T. Hampe: Die fahrenden Leute in der deutschen Vergangenheit. Jena 1924. 
gammel til. Man morede sig og drak rigeligt; uheldigvis så meget, at enkelte mistede besindelsen. På vejen hjem fra skuet kom det til slagsmål, og en anset borger blev dræbt. ${ }^{4}$

De slesvigske dyrefremstillinger er i sig selv blot kuriøse hændelser. På den anden side er de naturligvis tegn på, at den sønderjyske omverden blev verdensomfattende. Tidligere havde den blot været europæisk, men det til gengæld, i kraft af Romerkirken, i en udstrækning, som kan måle sig med vore dage. Religionen var fælles, menneskene var bevægelige. På pilgrimsrejser færdedes man i grupper over lange afstande: 1489 arrangeredes således en pilgrimsfart til Aachen fra Ejdersted, 1495 kom en ejderstedbonde tilbage efter at have besøgt valfartsstedet Santiago de Compostella i Spanien. ${ }^{5}$

Øjensynlig kan man $\mathrm{i}$ virkeligheden tale om, at det større verdensbillede fulgtes af en indskrænkning af det enkelte menneskes bevægelighed. Handelen er et godt eksempel på dette forhold. Hvor det gamle system var, at handleren fulgte sin vare, ser man i løbet af middelalderen og den tidlige nytid et professionelt fragtvæsen vokse frem. Købmanden kunne nu i højere grad blive i sin by og overlade transporten til skippere og fragtmænd. ${ }^{6}$ Et lige så klart udtryk for den faldende bevægelighed er administrationen. Tidligere regerede konger og fyrster landet fra sadlen; i løbet af 14-1500-tallet dannedes et mere stedfast bureaukrati. I 1500-tallet kunne det imidlertid stadig synes nødvendigt at flytte sig og ikke overlade budskabet til brevene. Herredsfogeden i Nørre Gos herred Paul Hansen afgik ved døden ved det 16. århundredes slutning, og hans arvinger stredes om arven. Da noterede en af parterne, Johannes Jessen (kaldet Pauli), hvordan han havde måttet rejse for at få retten på sin side: ${ }^{7}$

Ar 1595 og 1596. Fra Bredsted til Flensborg og tilbage igen 31 gange 4 mil . . . . . 124 mil

År $159627 / 1$ fra Bredsted til Svavsted .................... 3 mil

$28 / 1$ fra Svavsted til Bredsted $\ldots \ldots \ldots \ldots \ldots \ldots \ldots \ldots \ldots \ldots \ldots \ldots$

$28 / 2$ fra Flensborg til Haderslev $\ldots \ldots \ldots \ldots \ldots \ldots \ldots \ldots \ldots \ldots \ldots . \ldots \ldots$

$5 / 3$ fra Haderslev til Flensborg $\ldots \ldots \ldots \ldots \ldots \ldots \ldots \ldots \ldots \ldots \ldots$

$18 / 3$ fra Flensborg til Danzig $\ldots \ldots \ldots \ldots \ldots \ldots \ldots \ldots \ldots \ldots \ldots . \ldots \ldots$ mil

$6 / 4$ fra Danzig til Marienburg $\ldots \ldots \ldots \ldots \ldots \ldots \ldots \ldots \ldots \ldots$

$8 / 4$ fra Marienburg til Danzig $\ldots \ldots \ldots \ldots \ldots \ldots \ldots \ldots \ldots \ldots$

$13 / 4$ fra Danzig til Marienburg $\ldots \ldots \ldots \ldots \ldots \ldots \ldots \ldots \ldots \ldots \ldots$

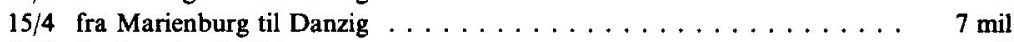

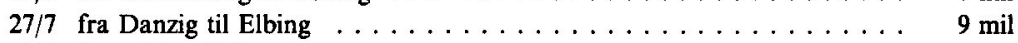

$3 / 8$ fra Elbing til Danzig $\ldots \ldots \ldots \ldots \ldots \ldots \ldots \ldots \ldots \ldots \ldots \ldots$

$15 / 8$ fra Danzig til Kronborg $\ldots \ldots \ldots \ldots \ldots \ldots \ldots \ldots \ldots \ldots \ldots \ldots \ldots$

$26 / 8$ fra Kronborg til København $\ldots \ldots \ldots \ldots \ldots \ldots \ldots \ldots \ldots \ldots . \ldots \ldots$

$8 / 9$ fra Kobenhavn til Kronborg $\ldots \ldots \ldots \ldots \ldots \ldots \ldots \ldots \ldots \ldots \ldots \ldots \ldots$

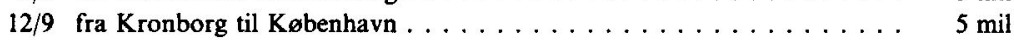

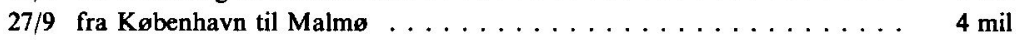

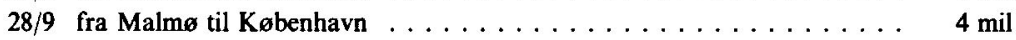

$30 / 9$ fra Kobenhavn til Frederiksborg $\ldots \ldots \ldots \ldots \ldots \ldots \ldots \ldots$ mil 
2/10 fra Frederiksborg til København $\ldots \ldots \ldots \ldots \ldots \ldots \ldots$ mil

$4 / 10$ fra Kobenhavn til Kronborg . . . . . . . . . . . . 5 mil

$6 / 10$ fra Kronborg til København . . . . . . . . . . . . . 5 mil

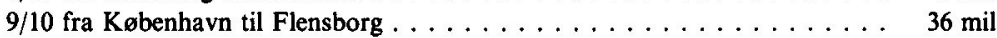

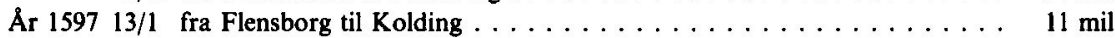

$24 / 1$ fra Kolding til Flensborg . . . . . . . . . . . . . . . $11 \mathrm{mil}$

$18 / 2$ fra Flensborg til Bredsted $\ldots \ldots \ldots \ldots \ldots \ldots \ldots \ldots \ldots \ldots$ mil

$21 / 2$ fra Bredsted til Husum $\ldots \ldots \ldots \ldots \ldots \ldots \ldots \ldots \ldots \ldots \ldots \ldots$

$22 / 2$ fra Husum til Bredsted $\ldots \ldots \ldots \ldots \ldots \ldots \ldots \ldots \ldots \ldots \ldots \ldots \ldots$

$23 / 2$ fra Bredsted til Flensborg $\ldots \ldots \ldots \ldots \ldots \ldots \ldots \ldots \ldots$ mil

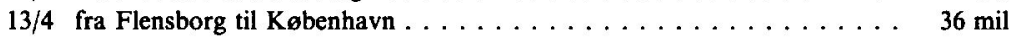

Den større omverden, der kunne strække sig mange hundrede mil væk, bør ikke glemmes, når man beskæftiger sig med lokalsamfundet. Den må medtænkes, når emnet er det 'mikrokosmos', som den almindelige sønderjyde i senmiddelalderen indgik i. Det er dette lokale niveau, vi nu skal ned til. Det skal forsøges at beskrive de typiske sønderjyske samlingssteder eller 'centralsteder' for større grupper af bønder, som de kan lokaliseres i tiden 1350-1600 - særlig før reformationen - og med en overvægt af eksempler fra Flensborg og omegn. $^{8}$

\section{Valfartssteder og årsmarkeder}

Idet vi bevæger os trinvis nedad mod det lavere niveau, skal det først undersøges, om der var centralsteder, der samlede landbefolkningen fra sterre regioner - inden for hertugdømmet, men på tværs af herreds- og lensgrænser.

Det store flertal af senmiddelalderens mennesker følte trang til pilgrimsfærd. Som det hedder hos Chaucer: 'Når april med sine milde regnbyger har gennemtrængt den tørre martsjord og badet hvert blad i sin væde ... da længes folk efter at drage på pilgrimsfærd'.. Den almindelige bonde tog imidlertid ikke til de store europæiske valfartssteder. Han opsøgte de lokale valfartskirker og kapeller. Her ærede høj og lav den helgen, stedet var viet til, og besøgte det marked, som fandt sted i tilslutning til helligdommen. Af disse valfartssteder lå der en hel stribe langs hærvejen, bl.a. kapellerne i Årup, Kliplev, Klues og Gettorp. Der er forsket en del $i$ deres historie, men kun ét sted kan man virkelig komme $\mathrm{i}$ dybden, $\mathrm{i}$ Gettorp. ${ }^{10}$ Herfra er der nemlig bevaret både regnskaber og 'skyldbøger'. Kurt Hector, der har analyseret kilderne, viser på grundlag af de solgte pilgrimsmærker udsvingene $i$ antallet af besøgende $i$ årene 1486-1532. Første registrerede år var 1486. Da kom der 950 købere af pilgrimstegn til Gettorp; i de følgende år faldt besøget indtil 1498, hvor det sprang op til 1800 personer. Fra da af og frem til 1525 kom ca. 1500 besøgende årligt. Herefter stod reformationen imidlertid for døren, og pilgrimmenes antal svandt til næsten ingenting; 1532 noteredes de sidste 100 solgte pilgrimstegn." 


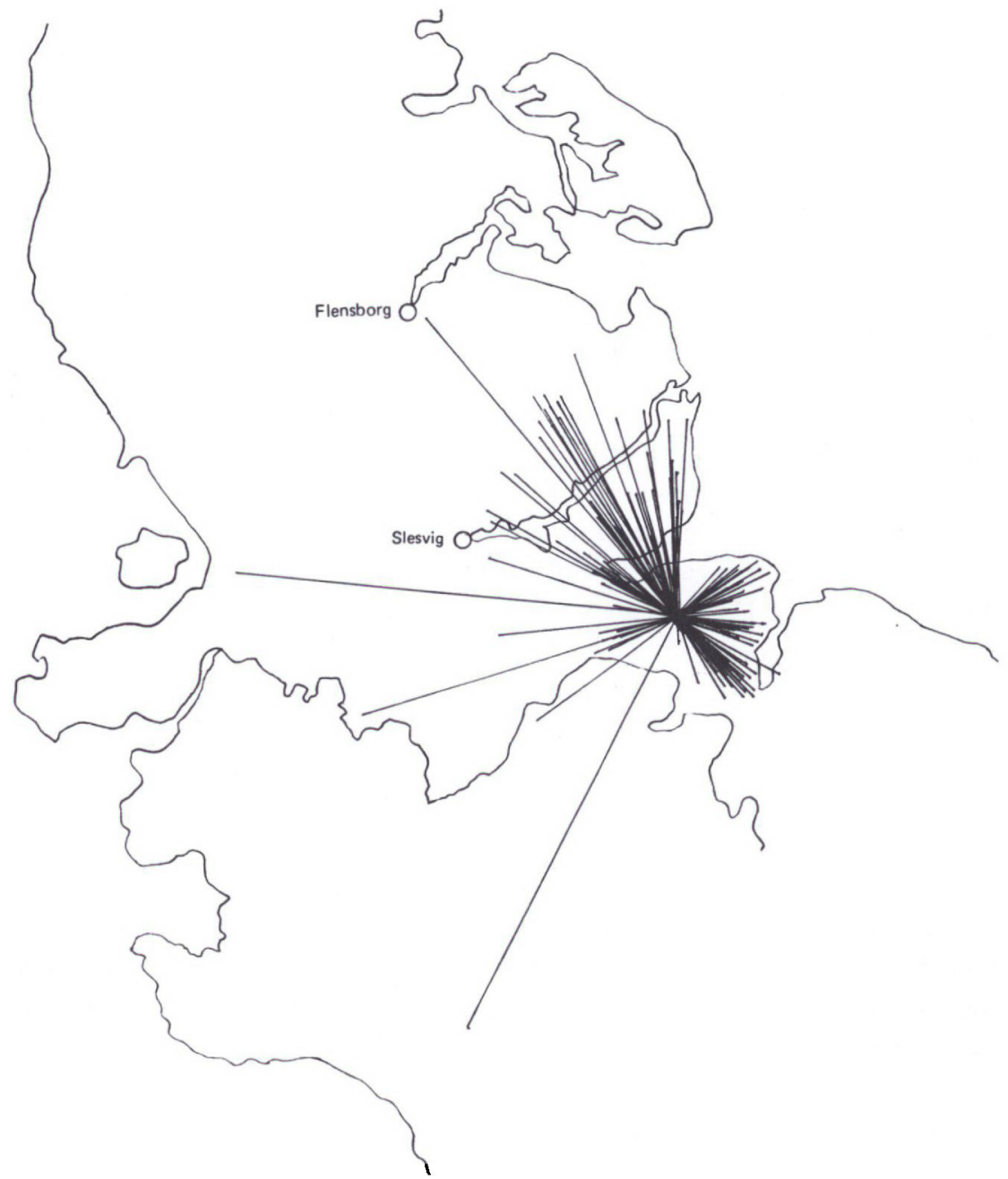

Kort 1. Pilgrimmes og markedsbesøgendes rejser til Gettorp 1486-1532. Hver streg angiver en rejse. Kilde: Hector, 1961 (s. 40).

I Gettorp kirkes skyld- og regnskabsbøger finder man oplysninger om hjemstedet for en lang række personer, der har besøgt valfartsstedet. En kortlægning af oplysningerne viser, at næsten alle kom fra den jyske halvøs østland, men fra et ganske stort område. Gettorps hovedomland ses at have været Kiels vestlige omegn, Dänischwohld, Svans og Angels sydlige del ${ }^{12}$ (kort 1). Valfartsstederne udgjorde altså mødesteder, der indtil reformationen samlede bønder fra en større region. 
Overalt i det danske rige blomstrede årsmarkeder frem i senmiddelalderen, til tider som i Kliplev og Lysabild forbundet med et valfartssted. Årsmarkederne fandtes såvel på landet som $\mathrm{i}$ byerne. 1493 omtales humleførernes salg på det frie årsmarked i Husum, som skulle vare tre dage, og fra samme år eksisterer der en efterretning om, hvordan der på kirkegården i Rørbæk (Beltring herred) på Nordstrand fandt sådanne markeder sted 17/3 og 22/9. I løbet af 1500-tallet fik byerne dog i stigende grad eneret på markederne. 1529 bestemtes det eksempelvis, at tre markeder, som hidtil havde været holdt $\mathrm{i}$ Ketting og Lysabild, skulle forlægges til Sønderborg, og 1530 flyttedes et årsmarked fra Rise kirke til Aabenraa. ${ }^{13}$ På markederne mødte bondebefolkningen købmænd og kræmmere fra fremmede byer og egne. De små landkræmmere samledes utvivlsomt i stort tal. Storbonden Backe Detlefsen, der boede i Maas, lige nord for Husum, gav ifølge sin regnskabsbog $i$ årene 1573-78 lån til en nærboende enke Hylle Hanses. Det ser ud til, at Hylle tjente til livets opretholdelse netop ved at drive småhandel på årsmarkederne - hun fik udbetalt 8 skilling 1574 'torsdagen før Bredsteds årsmarked', 1 mark 'torsdagen før Ribes marked' 1575 og 1 mark 'lørdagen før Læks marked' $1576 .{ }^{14}$ Kun sjældent oplyses vi om, hvilke varer bønderne transporterede til årsmarkederne. Der er dog næppe tvivl om, at det har været de landbrugsprodukter, som den enkelte gårds driftsform betingede et overskud af. Bredsteds årsmarked, som jo blev holdt i det kvægrige Vestslesvig, var karakteristisk nok det sted, hvor den flensborgske tjener Boye Ludsen i 1560 købte for 5 mark ost. En mere omfattende registrering af årsmarkedsbesøgende giver Gottorpregnskaberne fra 1485 og følgende år, idet de indeholder notitser om de frisere, der drog østpå til efterårsmarkederne i Rendsborg, Egernførde og Kiel. De tog afsted i store vogntog på 10-20 vogne lastede med smør, frisisk salt og det hjemmevævede klæde 'webbe'. Som returgods medbragte de normalt humle og lærred, men de kunne også, som kræmmersken Carstine fra Bredsted, udover disse varer, have en gryde med hjem. ${ }^{15}$

Det er næppe tilfældigt, at de bønder, der møder os i toldregnskaberne, stammer fra Vestslesvig. For her trivedes en særlig udviklet entreprenørånd, der gav stødet til lange rejser. Det var også disse vestslesvigske bønder, der hvert år mødtes på Helgolandsmarkedet, hvor borgere og bønder fra hele Nordsøområdet mellem Esbjerg og Holland udvekslede varer. ${ }^{16} \mathrm{Da}$ vi her begrænser os til det regionale og lokale, skal deres spor imidlertid ikke følges. Derimod skal den generelle konklusion fastholdes, nemlig at de to centralsteder, valfartssteder og årsmarkeder, i den tid, der her behandles, havde regional betydning og kunne samle betydelige dele af den sønderjyske landbefolkning. Årsmarkederne udøvede også i århundrederne, der fulgte, deres 
tiltrækning, mens reformationen betød, at den religiøse mobilitet begrænsedes til afstanden mellem hjem og sognekirke.

\section{Byerne: tilflyttere og udenbys gildemedlemmer}

Bymønsteret var allerede fastlagt i 1200-tallet. Da stod Haderslev, Aabenraa, Tønder, Sønderborg, Flensborg, Slesvig og Egernførde fuldt udviklede. I løbet af senmiddelalderen blev bylandskabet endnu tættere, da Ærøskøbing og flækkerne Kappel, Bredsted, Husum og Tilen (ved Ejderen) voksede frem. ${ }^{17}$ Disse bebyggelser kunne næppe opretholdes ved egen befolkningsvækst; de behøvede konstante tilførsler af indvandrere. Blandt dem, der aflagde borgerskabseden i Flensborg i tiden 1558-1600, kan nogle stedfæstes..$^{18}$ Nyborgere af sønderjysk oprindelse kom overvejende fra byens nære omland: 21 fra Angel, 14 fra midtgesten, 24 fra Aabenraa/Sønderborg/Nordborg len; færre var der fra Tønder/Løgumkloster len, nemlig 11; andre egne talte kun lidt - Nordfrisland 6, Ejdersted 2, Haderslev len 4. Dette billede er givetvis det normale i hele hertugdømmet. Det var det nære omland, der gav det store tilskud til byernes befolkning.

Selve integrationen $\mathrm{i}$ byen kunne ske på flere niveauer. Nogle kom til staden med en solid kapital optjent $\mathrm{i}$ landbruget. Jacob Petersen Oldendorph er et godt eksempel på de rige bønder, der uden problemer indgik i handelsborgerskabet. Opvokset på slægtsgården Gammelby ved Fjelstrup nord for Haderslev, drev han fra omkring år 1500 købmandshandel på landet og i Haderslev by. Snart købte han et hus ved Haderslevs torv og giftede sig 1509 ind i en velhavende ripensisk slægt. Med årene avancerede han til både rådmand og borgmester i Haderslev. Kvæg- og hestehandel og import af klæde synes at have udgiort fundamentet $i$ hans virksomhed, selv om også andre varer bl.a. vin indgik heri. ${ }^{19}$

Bønder af denne type rekrutteredes i Flensborg oftest blandt vestkystens beboere. Herfra kom rige og handelsvante indvandrere, som slægterne Paysen og Frese, der direkte kunne gå i kompagniskab med de gamle købmandsfamilier. Et udmærket kildemateriale belyser, hvordan denne omstilling forløb for Namen Jansen, der omkring år 1500 forlagde sin handelsaktivitet fra Vestslesvig, måske fra Hviding herred, til Flensborg og ligesom Jacob Petersen blev rådmand og fik hus ved bytorvet. ${ }^{20}$

Nogle bønder urbaniseredes altså på et højt niveau, andre af bondebefolkningen, f.eks. de fra fattige fæstegårde, blev blot tjenestefolk i byen og opnåede aldrig borgerskab. For dem alle kunne det være et problem at blive accepteret 
på det nye bosted. En række injuriesager fra Flensborg fra tiden 1505-25 viser, at de gamle borgere hyppigt fremsatte grove beskyldninger mod nytilflytterne - mænd blev beskyldt for tyveri, kvinder for hor. ${ }^{21} 1512$ sagde eksempelvis Laurens Badstuemester til Jep Madsen, at dennes bedstefader havde stjålet en fole og 'holdt den bundet så længe i skoven, at den døde'. Jep Madsen så sig da nødsaget til over for det flensborgske byråd at bevise, at bedstefaderen var en from arlig mand, som lå begravet på kirkegården i Vonsbæk, nord for Haderslev. ${ }^{22}$

En af de måder, hvorpå dette 'fremmedhad' formindskedes, var gennem det fælles medlemsskab i gilder. De mange religiøse gilder udgjorde et karakteristisk træk ved senmiddelalderen; alene i Flensborg fandt man Knudsgildet, Laurentius-, Drager-, Gertruds-, Vor Frue Købmands-, Nikolai-, Hellig Legems-, Vor Fruegildet. ${ }^{23}$ Gildernes medlemsskab lader sig kun sjældent gøre op, men netop fra Flensborg er det så heldigt, at flere fortegnelser over medlemmer er bevaret. ${ }^{24}$ Af disse skal St. Laurentiusgildets, St. Gertrudsgildets og Vor Frue Købmandsgildets lister betragtes, da der heri er adskillige navne på folk, som er karakteriseret ved landsbynavn. Det kan enten være knyttet til dem ved betegnelsen 'in'/'tho' eller ved 'de'/'van'. Vil man være sikker på, at gildemedlemmerne virkelig boede $i$ den landbebyggelse, de forbindes med, må man holde sig til den forste gruppe. Personer, der beskrives som fra ('de'/ 'van') kan være udenbys medlemmer, men kan også være tilflyttere, der boede i Flensborg.

Foretages denne sortering for St. Laurentiusgildet, nedbringes antallet af folk med angivelse af landsby fra ialt 53 til 23 . Af disse 23, som helt sikkert boede uden for byen, er de 18 medlemmer fra tiden 1377 til ca. 1400, resten fra årene 1504-12. Ser man på deres hjemsted viser det sig, at den ældste medlemsskare kom langt væk fra, overvejende fra Vestslesvig/Nordfrisland, mens to af den yngre del fra det 16. århundrede boede i Harreslev, lige uden for Flensborg, en med sin hustru ved Morkær kloster i Angel, og kun to havde bopæl langt borte, nemlig præsten fra Løjt, hr. Johan og (fogeden?) Marquart Schroder med hustru fra Avbæk i Løjt sogn ${ }^{25}$ (Kort 2).

Skt. Gertrudsgilde havde færre udenbys medlemmer. Her kan kun 5 personer udskilles. Ligesom i Laurentiusgildet falder deres medlemsskab tidligt, men i modsætning til dette gildes medlemmer kom Gertrudsgildets fra Østslesvig. 3 medlemmer - en i Hellevad (Hellevad s., Sdr. Rangstrup hd), en i Søderup (Hjordkær s., Rise hd) og en 'bosiddende i Veseby' (Hyrup s., Husby hd) tiltrådte gildet snart efter 1379. To andre landsbybeboere blev optaget i 1429 , heraf var den ene fra Kisby (Borne s., Strukstrup hd), den anden fra det ikke lokaliserbare 'Ustorp'. ${ }^{26}$

I løbet af 1400-tallet overtog Vor Frue Købmandsgilde pladsen som det 


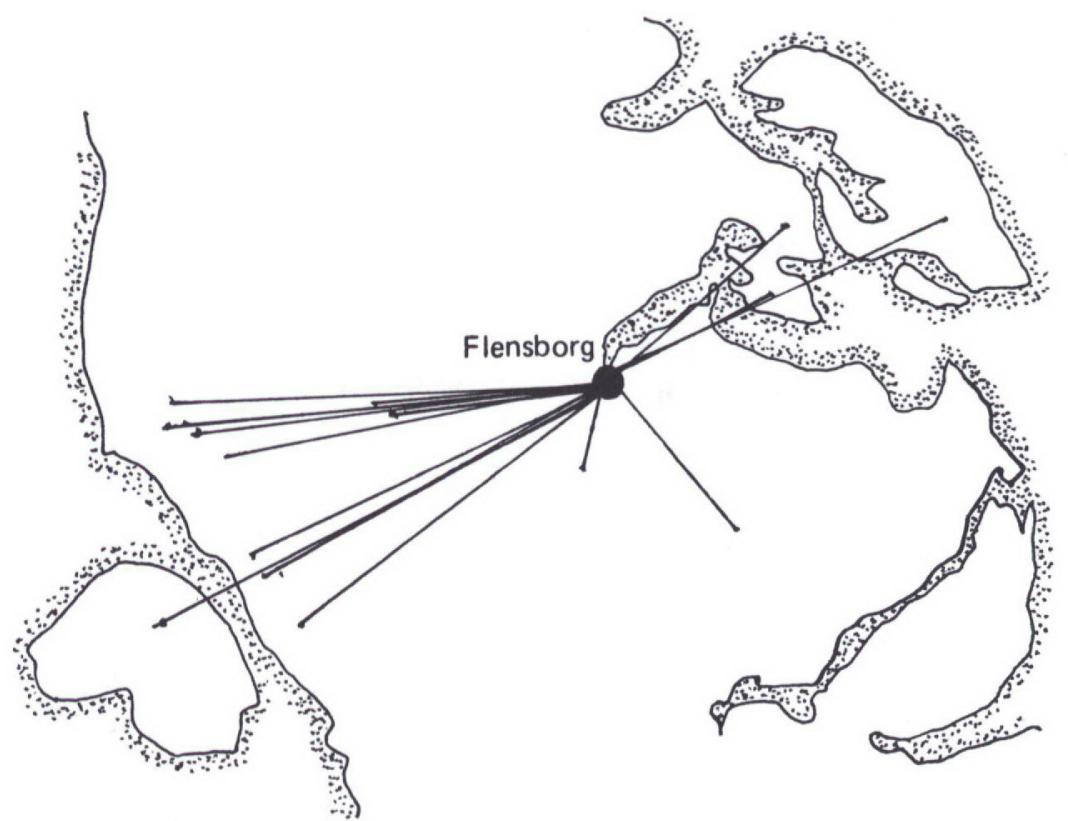

Kort 2. Udenbys medlemmer af St. Laurentiusgildet i Flensborg fra ca. 1377 til omkring 1400 . En streg angiver et medlem.

foretrukne selskab for udenbys gildemedlemsskab. For dette gilde kan i tidsrummet 1441-1517 udskilles 15 landsbymedlemmer - idet vi, som også ovenfor, ser bort fra adelige. Købmandsgildets medlemmer havde overvejende østslesvigsk bosted, de fleste i Flensborgs nærmeste opland. Interessant er det at se, hvordan en hel slægt - 'to Blanse' - fra Blans (Ullerup s., Sundeved) tilsluttede sig. 1441(-60) kom Jes Kalison med hustru, 1465 Nisse Jens Kallison med hustruen Margrethe, 1469 Symen Jesse Kallison med hustru og endelig 1471 Ludeke Jensson. ${ }^{27}$

Landboernes gildemedlemskab i bygilderne reflekterer utvetydigt følgerne af 1300-tallets økonomiske krise og den strukturomlægning i godsdriften, der bevirkede, at bondegårde voksede frem i de tidligere storgårdes sted. De friere og mere velsituerede bønder søgte tryghed $i$ andre fællesskaber end storgårdenes, og de var - ihvertfald forbigående - ansete nok til at kunne vælge disse $i$ byerne. Gilderne har været en af de organisationsformer, der drog bonden mod byen. Der fandtes dog endnu væsentligere årsager til bondebefolkningens orientering mod byerne. 


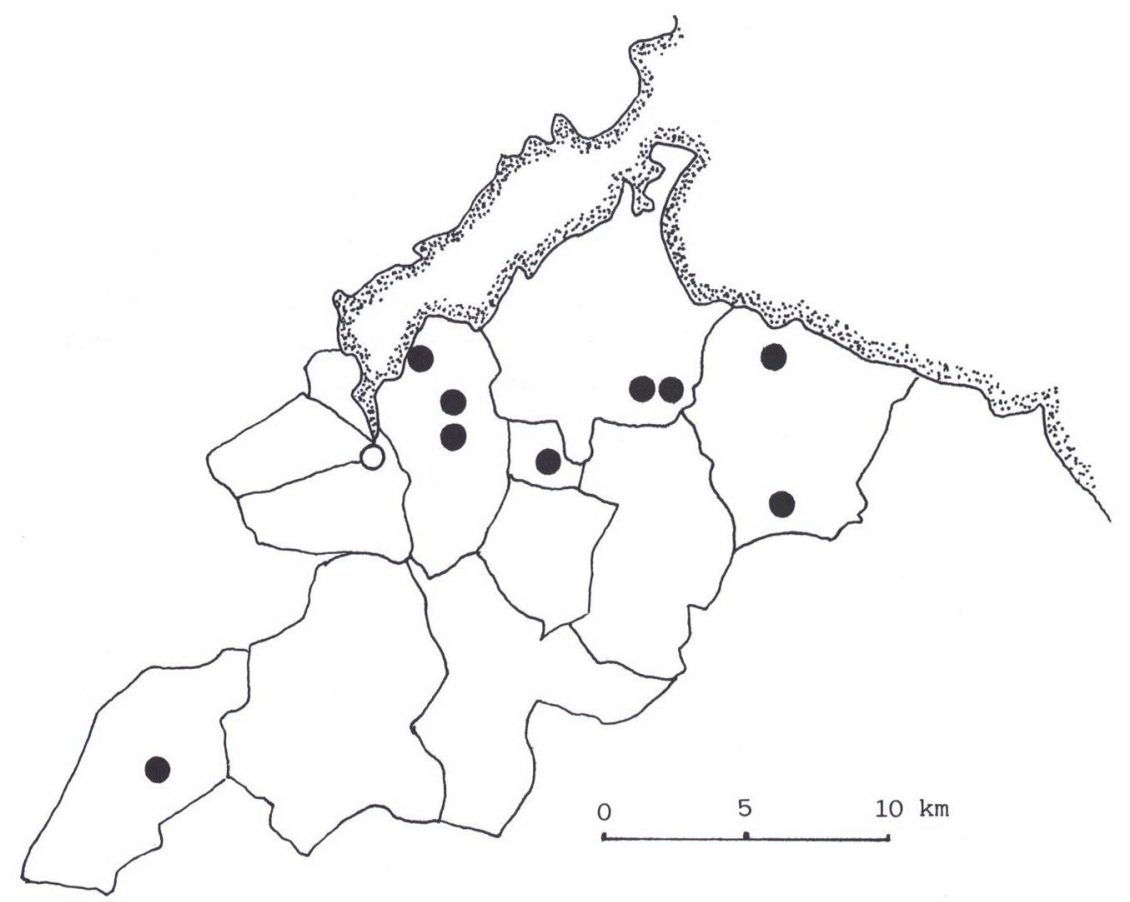

Kort 3. Landgods tilhorende St. Jorgensgården i Flensborg omkring 1450. Hvert punkt markerer en gård.

Byerne: landgods og bondehandel

Helt afgørende for samvirket land-by var den økonomiske nødvendighed. Byer og flækker var fuldstændigt afhængige af tilførsler fra de omgivende landdistrikter.

Det var et problem, der kunne løses ved, at borgere og byinstitutioner erhvervede besiddelser og rettigheder på landet. Denne proces er endnu for uudforsket til at noget samlende kan siges om den, men det ser ud til, at hvor jordbesiddelsen indtil 1400-tallet var knyttet til de gejstlige institutioner og gamle aristokratiske patricierslægter, så åbnede der sig herefter større muligheder for opkøb af landgods med købmandskapital. ${ }^{28}$ Gårde kunne da få skæbne som Visgård (Tinglev s., Slogs hd). Den ejedes ved 1400-tallets slutning af adelskvinden Anne Sture, der i 1494 solgte ejendommen til Løgumkloster. 1511 var klosteret imidlertid gerådet i økonomiske vanskeligheder, og Visgård blev nu pantsat til den flensborgske købmand Peter Nielsen for købssummen, 200 rhinske gylden. Frem til midten af 1500 -tallet kunne købmanden og hans efterkommere i Flensborg nyde godt af landgilden på årligt 8 mark lybsk, et 
svin, når der var olden, samt ret til 'gæsteri' på gården. ${ }^{29}$ De gejstlige institutioner $i$ byerne ejede gennemgående, selv for de mindstes vedkommende, noget landgods. St. Jørgensgården i Flensborg besad eksempelvis omkring 14509 gårde og havde pant i en (kort 3), mens Helligåndshuset i samme by på denne tid havde ejendomsret til 24 gårde og panteret til en. ${ }^{30}$

Fra landet kom der altså, når landgildeterminen indtraf, vandrende bønder med afgifter i form af korn, svin, gas og andet til deres byherrer. Flere bønder drog dog til byen for at sælge deres varer. Landboerne havde et salgsoverskud, og de behøvede bymarkeder for at kunne afsætte det. Naturligt dannedes der da omkring hver by et fast opland, fordi man selvfølgelig ofte søgte til nærmestliggende by. Dette opland søgte byerne at monopolisere, idet de havde en klar interesse $i$ at tiltrække landbefolkningen fra et så stort område som muligt og $i$ at udelukke handel fra landdistrikterne. Deres bestræbelser kunne ofte opnå støtte fra fyrstemagten ved regulær lovgivning: 1354 befaledes det, at indbyggerne fra Hviding-, Lø-, Slogs-, Højer- og Tønder herred kun måtte handle i Tønder; 1474-81 blev det fremmede forbudt at handle med andre p̊̊ Als end indbyggerne i Sønderborg; 1496 forordnedes det, at kun Haderslevs borgere måtte købe korn, heste, okser, smør, honning og andre varer i Haderslev len; 1522 forbød Christian II til fordel for Ærøskøbing, at købmandsskab blev udøvet $\mathrm{i}$ landsbyerne på Ærø. ${ }^{31}$ Med hensyn til Flensborg ser man tydeligt, hvordan kongerne efter hertugdømmets deling i 1490 forsøgte at fremme byens vækst. 28/7 1491 forordnede kong Hans, at alene flensborgere måtte handle med bønder i hele det store Flensborg len. ${ }^{32} 7 / 111491$ gik han videre og bestemte, at indbyggerne fra Als og Sundeved skulle bringe deres korn og andre varer til torvs i Flensborg. I realiteten var der hermed erklæret handelskrig fra flensborgernes side. Man gik på togt i sønderborgernes opland. ${ }^{33}$ For de alsiske bønder var splittelsen mellem at handle i Sønderborg eller i Flensborg sikkert allerede af ældre dato. I årene efter 1474 påbød kong Christian I, at sønderborgerne skulle købe og sælge til de priser, der gives i Flensborg. ${ }^{34}$ Der blev imidlertid med det samme givet en dispensation, idet det frisiske salt måtte sælges 1 skilling dyrere i Sønderborg end i Flensborg. Det var oplagt for den alsiske bonde selv at stryge den avance, der var tiltænkt sønderborgerne. Vi ved faktisk, at han gjorde det; 1534 købte Olef Geriksen fra Brandsbøl eksempelvis 1 tønde salt i Flensborg, og 1537 var Per Henriksen fra Dyndved $\mathrm{i}$ byen for at købe 1 tønde salt. Byernes oplande gjaldt kun i relativ forstand, de blev regelmæssigt brudt.

I almindelighed er det svært at vide, hvilke varer bønderne solgte og købte i byerne. Det er imidlertid så heldigt, at der fra Flensborg er bevaret en enestående kilde, der gør det muligt at komme sagen nærmere, og hvorfra oplysningerne om de alsiske bønders saltkøb kunne hentes. Kilden er den 
flensborgske købmand Namen Jansens 'skyldbog' fra årene 1528-1549. ${ }^{35}$ Denne store protokol indeholder nøjagtige varekonti for hundreder af bønder $\mathrm{i}$ et stort område strækkende sig langs hele veskysten op til Tønder, men også i Flensborgs omland på gesten og i østlandet. En fuldstændig bearbejdelse kan endnu ikke gives; men undersøges skal i det mindste et enkelt herred, Vis herred vest og nord for Flensborg, hvor Jansen havde et rimeligt overskueligt antal kunder.

Namen Jansens kunder $\mathrm{i}$ Vis herred fordelte sig med $3 \mathrm{i}$ Bov sogn, $16 \mathrm{i}$ Hanved sogn, 9 i Nørre Haksted sogn og 9 i Store Vi sogn (kort 4). Lad os se på enkelte af disse landkunder, idet vi starter i Bov sogn. I Bommerlund modtog Regele Jensen, der antagelig var faster under Søgård, i 1532 201/2 alen blåt klæde fra Harderwijk i Nederlandene. Til gengæld leverede han 2 okser til Namen Jansen for 12 $\frac{1}{2}$ mark. I Kollund boede borgmester i Tønder Johan Ketelsens fæster Jes Iversen. Han havde i årene 1533-48 stadige transaktioner med Namen Jansen: 1533 og 1536 fik han malt, 1534 salt, 1536 og 1537 humle, 1542 klæde. Til gengæld leverede han rug, saltet svin og gæs til Jansen. Betalingen reguleredes yderligere ved, at Iversen kørte tørv for købmanden og græssede hans hest. I Hanved sogn fandt man Hans Burensen, der boede i Ellund. Han købte 1531 sort klæde og 1 tønde mel. Det betalte han med 2 rhinske gylden, 1 mark, hø til 11 skilling og rug til 18 skilling. Skovlund i Nørre Haksted sogn var bl.a. beboet af mølleren Anders Moller, der var fæster under Slesvig Domkapitel. Til ham solgte Jansen i 15281 dromt humle til 28 skilling. Peter Hansen fra Lille Vi i Store Vi sogn handlede i årene 1528-34 med Jansen. En fast leverance fra ham var smør i tønder, til gengæld gav købmanden ham bl.a. penge, hør, 1 kniv, 1 tønde sild og øl. I kirkebyen Store Vi købte kromanden, der var fæster under Lindevedgård, i 1535 en tønde sild, mens byens præst Hr. Johan Tochsen, i 1531 fik leveret øl, humle, sild, hvidling og ost. ${ }^{36}$

Tager man et overblik over varerne, ses det, at bønderne solgte deres overskudsproduktion af enhver art, og $\mathrm{i}$ almindelighed erhvervede basale goder som humle, salt, sild og hør. Samtidig er det tydeligt, at luksusvarer, bl.a. det dyre hollandske klæde, hyppigt fandt vej til bøndergårdene, og at der her var ret store kapitaler i rede penge. ${ }^{37}$

Namen Jansens regnskab angiver, at torvehandelen langt fra udgjorde den vigtigste omsætningsform mellem land og by. Mere betød øjensynligt overførslerne mellem købmændenes kramboder og bøndernes gårde. Denne kontakt var effektiv og ikke nødvendigvis personlig - ofte sendte bønderne for at udføre transaktionerne med Namen Jansen blot deres døtre, sønner, fædre, brødre eller naboer.

Der flød en bred kommerciel strøm mellem land og by. Mange muligheder 


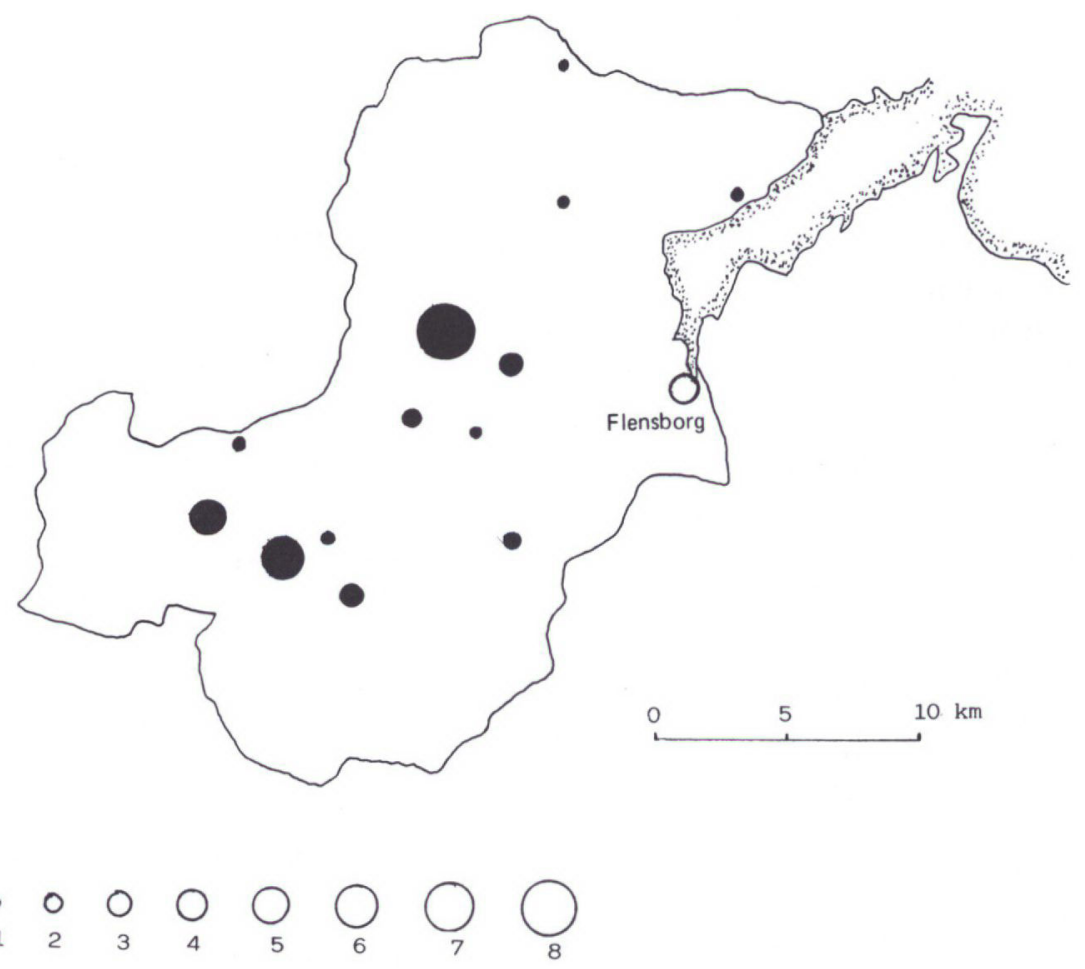

Kort 4. Namen Jansens kunder $i$ Vis herred 1528-1549.

stod åbne for markedsføringen af landbrugsvarer. Man kunne, som bylovgivningen forventede det, gå til torvet og sælge, man kunne, hvad Namen Jansens regnskab tyder på var det mest udbredte, have konto hos en bykøbmand, og endelig angiver artiklerne fra et købmandsgilde i Haderslev fra omkring år 1500 en tredje vej. Det hedder: 'Og skal ingen unde eller leje bønderne husrum, for at de kan sælge gods mod byens rettigheder og gamle skik' ${ }^{38}$ Bønder kunne altså selv søge at etablere permanente udsalgssteder $\mathrm{i}$ en by. Springet fra en sådan bod til egentligt borgerskab har været lille.

Valfartsstederne, årsmarkederne, byerne var de centralsteder, som tiltrak den senmiddelalderlige sønderjyske bondefamilie. Det var her de store masser mødtes, det var her de fleste fik tilfredsstillet deres videregående religiøse, økonomiske og sociale behov. Over for disse fænomener repræsenterer pilgrimsrejser til Spanien og forbikørende løvinder kun oplevelser for den enkelte. 


\section{NOTER}

1. A. H. de Oliveira Marques: Portugal Quinhentista. Lisboa 1987 (s. 46).

2. T. Hampe: Die fahrenden Leute in der deutschen Vergangenheit. (2. opl.) Jena 1924.

3. Danmarks Middelalderlige Regnskaber I, 1. Kbh. 1953 (s. 572-3).

4. A. Sach: Geschichte der Stadt Schleswig. Schleswig 1875 (s. 158-9).

5. Chronicon Eiderostadense vulgare oder die gemeine Eiderstedische Chronik 1103-1547, von Johannes Jasper, mit einer Ubersetzung ins Hochdeutsche von Claus Heitmann. St. Peter-Ording 1977 (s. 68, 70). Flere eksempler på pilgrimsrejser fra Sønderjylland hos L. Andresen: Wallfahrten. Die Heimat 42. 1932 (s. 73-79).

6. Jfr. B. Poulsen: Land-By-Marked. To økonomiske landskaber i 1400-tallets Slesvig. Flensborg 1988 (s. 152-4).

H. Lütjohann: Das Personen- und Frachtfuhrwesen in Schleswig-Holstein, I-II. Nordeibingen. Beiträge zur Heimatforschung in Schleswig-Holstein, Hamburg und Lübeck, Bd 15, 1939 (s. 25582) og Bd 16, 1940 (s. 159-97).

7. La Sch. Abt $65.1 \mathrm{nr} 956$ (1563-1599).

8. Centralstedernes historie udforskes i disse år aktivt. Metodisk grundlæggende er W. Christaller: Die zentralen Orte in Südwestdeutschland. Jena 1933. Ang. vandringer se bl.a. G.Jaritz og A.Müller (udg): Migration in der Feudalgesellschaft. Frankfurt/New York 1988.

9. Citeret i M. Boisens oversættelse fra Canterbury Fortællingerne af Geoffrey Chaucer (2 opl.). Kbh 1972 (s. 9).

10. Se i almindelighed H. Becker-Christensen: Hærvejen i Sønderjylland. Aabenraa 1981 (s. 50-4 og under de enkelte lokaliteter).

Kliplev - H.V. Gregersen: Messe og Marked. Haderslev 1974.

J.K. Hansen: Sct. Hjælper i Kliplev kirke. SJy Årb 1986 (s. 37-55).

H.V. Gregersen: Skt. Hjælper. En randnote til en afhandling i Sønderjyske Årbøger 1986. SJy Arb 1987 (s. 194-7).

J.K. Hansen: Svar på randnote. SJy Årb 1987 (s. 197).

N.K. Liebgott: Metaldetektorer og middelalderens fromhedsliv. Festskrift til Olaf Olsen på 60års dagen den 7. juni 1988. Kbh 1988 (s. 210-11).

Arup - H.V. Gregersen i Ensted Sogns Historie (red L. N. Henningsen), Skrifter udg. af Hist. Samf. for Sønderj., nr 64, 1987 (s. 40-5).

Jfr H.V. Gregersen: Gettorp og Årup som valfartssteder. Sønderj. Månedsskrift, 41, 1965 (s. 226-227).

J. S. Jensen: Et møntfund fra Årup valfarts kapel. Sønderj. Månedsskrift, 50, 1974 (s. 1-5).

Klues - O. Harck: Klus - et middelalderligt valfartssted ved Flensborg. SJy Årb 1962 (s. 14253).

Et muligt St. Jørgenskapel i Oversø - Becker-Christensen: Hærvejen (s. 200).

Gettorp - K. Hector: Die Gettorfer Schuldbücher von 1494 bis 1534. Jahrbuch der Heimatgemeinschaft des Kreises Eckernförde, 17. Jahrgang, 1959 (s. 143-51).

K. Hector: Die Kirche und das Kirchspiel Gettorf im ausgehenden Mittelalder. Jahrbuch der Heimatgemeinschaft des Kreises Eckernförde, 19. Jahrgang, 1961 (s. 7-74).

Eksempel på et af de små kapeller uden for hærvejen er St. Josts kapel (Adelby sogn, Husby hd). Repert II, nr 1827, 1828. Kapellet er afsat på Mejers kort over Angel 1649.

11. K. Hector: Die Kirche, 1961 (s. 38).

12. K. Hector: Die Kirche, 1961 (s. 39-41).

13. Da Gl Kbst Lovg, I (s. 83). R. Hansen (udg.): Johannes Petreus' Schriften über Nordstrand. Kiel 1901 (s. 6).

LA. Pergamentsbreve. Top. Sønderborg (1529 30/9), Rise (1530 14/6).

Jvfr. E. Kjersgaard: Markedsplads og markedsorganisation i middelalder og nyere tid. Købstadsmuseet. 'Den Gamle by'. Árbog 1983 (s. 25-48).

14. Stadtarchiv Husum. Rechnungsbuch Walke Widdesen. D 2/H 1318a. 
15. Note 35 anf. kilde. P. Enemark: Friesischer Handel zwischen ca. 1500 und 1700 . Nordfriesisches Jahrbuch, 1966 (s. 90-100).

B. Poulsen: Land-By-Marked (s. 107, 143).

16. Jfr B. Poulsen: Land-By-Marked (s. 178-80).

17. Senest om bymønsteret A. Andrén: Den urbana scenen. Städer och samhälle i det medeltida Danmark. Malmö 1985. Jfr min anmeldelse heraf i Historisk Tidsskrift, Bd 88, 1988 (s. 117120).

18. E. Hoffmann: Die Herkunft des Bürgertums in den Städten des Herzogtums Schleswig. Quell Forsch, 27, 1953 (s. 129-31, 245).

19. A. Andersen (udg): Johannes Oldendorphs Selvbiografi. En præsteskæbne fra Haderslev i hertug Hans den Fldres tid. Skrifter, udg. af Hist. Samf. for Sønderj., nr 34, 1966 (s. 12-18).

20. En af vestkystens bondearistokratiske slægter og dens forbindelse til Flensborg er nyligt behandlet af A. Schmidt: Die Froddesens von Toftum. Teil 1. Nordfriesisches Jahrbuch, N. F., Bd 24, 1988 (s. 93-126).

Ang. Namen Jansen se de mange kilder i H.C.P. Sejdelin: Diplomatarium Flensborgense. I-II. Kbh 1865-73 og den note 35 anførte kilde. O.H. Moller: Vermischte Nachrichten und Urkunden, welche den Stifter der lateinischen Schule in Flensburg, LUDOLPHUM NAAMANI, und dessen Eltern, wie auch der Franziskaner-Ordens und dessen Schicksale in Dänemark, insbesondere zur Zeit der Reformation, betreffen. Flensburg 1775. At Namen Jansen skulle stamme fra Hviding herred formodes af A. Panten i en endnu upubliceret afhandling 'Die Familie Lütke Namens'. Ifølge oplysninger fra G. Kraack boede N. Jansen først Holm 7 i Flensborg. Dette hus solgte han 1519 og flyttede til Søndertorv 5.

21. Ang disse sager se B. Poulsen: Flensborgere i middelalderen. i B. Poulsen (udg): Flensborg i middelalderen. Flensborg 1988 (s. 30-33).

22. Sejdelin: Dipl Fl II (p 13-14).

23. Ang Flensborgs gilder se G. Kraack: Das Gildewesen der Stadt Flensburg. Flensburg 1969. Gildernes rolle i integreringen af land og by fremhæves også hos K.-J. Lorenzen-Schmidt: Zur Struktur und Funktion der Wilsteraner Heiligen-Leichnams-Bruderschaft von 1500 bis 1564 . Kieler Blätter zur Volkskunde, XII, 1980 (s. 69-84).

24. De er trykt hos Sejdelin: Dipl Fl og C. Nyrop: Danmarks Gilde- og Lavsskraaer fra Middelalderen. I-II. Kbh 1895-1904. En ikke differentieret liste over udenbys gildebrodre i Flensborgs gilder hos G. Kraack: Das Gildewesen (s. 245-6).

25. Nyrop: Danm Gilde- og Lavskr I (s. 111-8). Ang identifikationen af 'Holtegorth' (p 112) se A.A. Panten: Das Kirchspiel Medelby in alter Zeit. Jahrbuch für die Schleswigsche Geest, 1987 (s. 22). Ang. Avbak se H.V. Gregersen i Løjt Sogns Historie (udg H.H. Worsøe), Skrifter udg. af Hist. Samf. for Senderjyll., nr 66, 1988 (s. $31 \mathrm{ff}$ ).

26. Nyrop: Danm Gilde- og Lavskr I (s. 133-49).

27. Nyrop: Danm Gilde- og Lavskr I (s. 592-604). Fra Fruerlund (Adelby s., Husby hd) er der et yderligere eksempel på, at en søn blev medlem efter faderen (s. 595 - 'Jeppe Peterson cum vxore to Fruerlunt' bliver medlem 1468, s. 601 - 'Peter Jepson cum vxore to Fruwerlunt' medlem 1498).

28. B. Poulsen: Land-By-Marked (s. 93 ff med litteraturhenvisninger).

29. M. Mackeprang: Løgum Kloster og dets Gods. Sønderj. Aarb. 1945 (s. 72, 73). Sejdelin: Dipl Fl II, nr 268, 552. E. Andersen (udg.): De Hansborgske Registranter, II, Kbh 1949 (s. 468 ).

30. Sejdelin: Dipl Fl I, nr 139, 140.

31. Da Gl Kbst Lovg I (s. 233, 287, 280, 293).

32. Da Gl Kbst Lovg I (s. 204).

33. Da Gl Kbst Lovg I (s. 205).

34. Da Gl Kbst Lovg I (s. 287).

35. Stadtarchiv Flensb. Altes Archiv. B. Königliches Gymnasium, nr 565.

36. Bommerlund under Søgård, SJy Sk Jb (s. 426, 428). Johan Ketelsens fæster i Kollund smstd (s. 443). Møllen i Skovlund se bl.a. H. Petersen: Geschichte der Mühlen zwischen Eider und Königsau. Neumünster 1988 (s. 187). Om Kroen i Lindeved A.A. Panten: Ein Pachtbauernver- 
zeichnis von Lindewithgaard aus dem Jahre 1510. Jahrbuch für die Schleswigsche Geest, 1982 (s. 64).

37. Ang bøndernes forhold til penge se B. Poulsen: Mønter i den senmiddelalderlige danske agrarøkonomi. Hikuin 11 (s. 227-36).

38. Nyrop: Danm Gilde- og Lavskr II (s. 242, §16). 